\title{
Customer Brand Co-Creation Behavior: \\ Conceptualization and Empirical Validation
}

\section{Structured abstract}

Purpose: This paper expands on existing co-creation knowledge in order to accurately conceptualize, operationalize and contextualize the customer brand co-creation behavior concept from a customer perspective.

Design: A quantitative approach is adopted in this study, using structural equation modelling to verify the co-creation of brand value for those customers who co-create.

Findings: A new four-dimensional co-creation behavior concept is supported, highlighting the role of development, feedback, advocacy and helping, in the co-creation of brand value. Further, a range of customer-level and brand-level antecedents are empirically verified. Research implications: The research takes a customer-centric view of co-creation and in doing so provides new insight into the effect on the co-creator. Additionally, the research offers an improved level of specificity in the co-creation domain by conceptualizing, operationalizing and contextualizing customer co-creation in a comprehensive research study.

Practical implications: Findings offer new insight to brand managers, identifying avenues for increasing customer participation in co-creation programs and critically, highlighting that cocreation behavior has positive effects on the co-creator's perception of brand value.

Originality: The customer-centric approach offers an original perspective from which to explore co-creation, demonstrating the positive potential of co-creation in brand management strategies. 


\section{Introduction}

The importance of co-creation in the contemporary branding environment highlights the redistribution of control from the firm to the customer. This altered setting brings co-creation to the forefront of marketing while also demanding critical reflection upon the changing context in which modern brands evolve. Crucially, from a branding perspective, the notion of co-creation centers on how the active contribution of various stakeholders determines brand success (Ind and Coates, 2013). A growing number of brands are embracing co-creation as a new support mechanism for competitive advantage (Ramaswamy and Ozcan, 2014) and while there is exponential growth in theoretical discussion of co-creation, only about $13 \%$ of the research resides purely in the marketing domain (Galvagno and Dalli, 2014), and an even smaller percentage within the branding context. Given that successful brand management is an essential factor to effective business performance (Merz et al., 2009), identifying the impact of co-creation upon the brand becomes crucial. Therefore, as the need to understand and manage co-creation continues to be recognized, there remains significant scope for theoretical and empirical research development within the brand management domain.

The nucleus of co-creation theory is firm and process oriented. Hence, a paradox has emerged whereby, on one hand, increased customer influence stimulated growth in cocreation research, yet, on the other hand, much research in this area neglects the customer perspective. Resolution of the paradox lies in development of customer centered co-creation theory. Co-creation is broadly understood to reflect the active role of the customer (Minkiewicz et al., 2014), yet little is known about the nature of this concept, i.e. its dimensionality, operationalization and nomological network. This paper addresses these 
oversights through deconstructing existing knowledge in order to conceptualize, operationalize and contextualize customer brand co-creation behavior ( $C B C B)$, providing precise articulation which enables stronger links between theory and practice (Corcoran, 2007). In doing so, this research bridges the branding perspective and the customer perspective, to identify brand strategy implications of co-creation behavior.

\section{Conceptual Development}

The co-creation construct is increasingly discussed, with multiple definitions at the ideological level (i.e., Vargo and Lusch, 2004) and managerial process levels (i.e., Payne et al., 2008). Yet, there is little evidence of a consistent approach to defining co-creation at the behavioral level (France et al., 2015), specifically from the customer's perspective, resulting in contradictions in the inclusion and exclusion of specific behaviors across various studies (Ind et al., 2012). Yet, there are some essential characteristics, gleaned from the developing literature, which allude to the nature of $\mathrm{CBCB}$ and form the basis for the proposed definition.

\section{CBCB Defined}

The behavioral participatory aspect of co-creation (Grönroos, 2008) is fundamental, in that the participation of actors is both voluntary and active. In terms of volition, customers make the choice to participate, although not required to do so (France et al., 2015). In addition, behavioral participation requires customer effort thus exemplifying the active (Ind et al., 2013), rather than passive, nature of behavior. On this basis, $C B C B$ is distinguished from the psychological state and is conceptualized as a behavioral phenomenon, supporting the view of France et al. (2015). Further, CBCB is underpinned by interactivity, where reciprocal influence for both the co-creator and the brand emphasizes the 'co' in co-creation and 
highlights the contribution of multiple players interacting to create the brand (Ramaswamy and Gouillart, 2010), both directly and indirectly (France et al., 2015). By virtue of this interactivity, CBCB becomes entwined in the customer-brand relationship (Payne et al., 2009). As such, CBCB is appropriately defined as the voluntary, active and interactive customer actions associated with the customer-brand relationship.

\section{CBCB Behavioral Dimensions}

The most comprehensive view of $\mathrm{CBCB}$, underpinned by customer participation and customer citizenship behaviors, is that of Yi and Gong (2013) who argue that co-creation, in the context of services, involves feedback, advocacy, helping and tolerance. The first three dimensions (i.e. feedback, advocacy and helping) appropriately align with the definition of CBCB proffered in this paper. The tolerance dimension, defined as the willingness to be patient when expectations are not met (Yi and Gong, 2013, p. 1281), is perceived as passive and, thus, does not align to the active nature of $C B C B$ and subsequently is excluded in this study.

Co-creation feedback involves providing the brand, solicited and unsolicited, evaluations of brand experiences (adapted from Yi and Gong, 2013). Feedback has a relatively low resource investment for the customer and in most instances; there is a low level of public visibility to the behavior. Yet, feedback co-creates directly with the brand by enhancing understanding of the customer experience and providing knowledge for improvement, which may shape the way the brand is delivered. 
The dimension of co-creation advocacy involves the voluntary customer behavior of recommending the brand to others (Yi and Gong, 2013) and is influential in co-creation (Payne et al., 2009). Advocacy behavior is largely emotional in nature, involving less cognitive resources but having high social risks in the customer-to-customer environment and indirect interaction with the brand. In the contemporary environment, where brand related discussions may occur in online forums (Wirtz et al., 2013), advocacy behavior may be highly visible or can occur in more intimate settings. Irrespective of whether public or private, cocreation advocacy has the potential to directly influence how others perceive the brand and as such, may co-create the brand.

The helping dimension of $\mathrm{CBCB}$ includes voluntary customer participation in assisting other customers to enhance their experience of the brand (Yi and Gong, 2013). While not a dominant area of co-creation research, support from other customers may have a significant influence on how the brand is perceived (Yi and Gong, 2013), and, therefore, becomes essential in formulating a holistic view of co-creation. The nature of co-creation helping is often cognitive problem solving, largely relating to explanation and description. Helping behaviors indirectly interact with the brand, occurring in a customer-to-customer sphere, but centered on the brand.

Additionally, the popular area of co-creation development is relevant to this discussion. Relating to voluntary customer participation in the generation of new ideas and resources for the brand, co-creation development, encompasses the co-creation of new product ideas (Hoyer et al., 2010; Ramaswamy and Gouillart, 2010), new advertising (Thompson and Malaviya, 2013), and the likes. Co-creation development is one of the most discussed and 
increasingly practiced areas of co-creation. Co-creation development behavior is highly active in nature, involving a significant investment of cognitive effort, and potentially other resource investment, on behalf of the customer (Prahalad and Ramaswamy, 2004; Thompson and Malaviya, 2013). For example, new product development often involves substantial ideation and an investment of time, effort and skill, on the part of the co-creating customer. Customer development behavior is considered co-creative, as the behavior provides an opportunity to directly adjust the brand offering, or to adjust how the brand, and its various elements, are perceived by other customers. Therefore, considering the voluntary, active and interactive nature of co-creation development, it is proposed as essential to a comprehensive view of CBCB. On this basis, the dimensionality of $C B C B$ includes a broad mix of active customer behaviors (i.e. development, feedback, advocacy and helping), each of which involves varying levels of active intensity and interaction with the brand in support of the customer-brand relationship.

\section{CBCB Antecedents and Consequences}

Given the very nature of co-creation, it is important to consider the influence of both customer-level and brand-level variables on CBCB. One of the few studies providing direction in this respect is that of France et al. (2015) who, through a series of propositions, identified key customer-level variables as category involvement, brand engagement and brand selfcongruity and brand-level variables as brand communities and brand interactivity. Drawing on this framework, the interplay between these variables is further examined and the subsequent hypothesized model presented. Yet, before preceding into the model discussion, it is useful to consider the emerging evidence in the domain, to establish the current state of 
knowledge. Co-creation literature is led by a high-level conceptual approach with specific branding areas (for instance, advocacy and feedback research) providing empirical discussions of antecedents and consequences of various co-creation behavior in goods, service or overall brand contexts, see Table. 1.

Table 1. Empirical co-creation antecedents

\begin{tabular}{|c|c|c|c|}
\hline Construct & Goods & Service & Brand (overall or mixed studies) \\
\hline \multirow[t]{3}{*}{ Involvement } & - Dwivedi (2015) & & \\
\hline & - Fetscherin et al. (2014) & & \\
\hline & - Tregua et al. (2015) & & \\
\hline \multirow[t]{5}{*}{ Engagement } & - Dwivedi (2015) & - Black et al. (2014) & - De Vries et al. (2012) \\
\hline & - Hseih (2016) & - Bowden (2009) & - Vernette (2013) \\
\hline & - Tregua et al. (2015) & - Brodie et al. (2011) & \\
\hline & & - Celuch et al. (2015) & \\
\hline & & - Merz et al. (2009) & \\
\hline \multirow[t]{3}{*}{ Congruity (Identity) } & - Ahearne et al. (2005) & - Black et al. (2014) & - Tuškej et al. (2013) \\
\hline & - Hseih (2016) & & \\
\hline & - Marzocchi et al. (2013) & & \\
\hline \multirow[t]{3}{*}{ Interactivity } & & & - France et al (2016) \\
\hline & & & - Kim \& Slotegraaf (2015) \\
\hline & & & - Labrecque (2014) \\
\hline \multirow[t]{3}{*}{ Community } & - Marzocchi et al. (2013) & - Black et al. (2014) & - Healy \& McDonagh (2013) \\
\hline & & & - Iglesias et al. (2013) \\
\hline & & & - Ind et al. (2013) \\
\hline
\end{tabular}

Results of analysis reaffirm the particular variables of interest identified by France et al. (2015) as relevant in the brand co-creation environment. Furthermore, an opportunity is highlighted to consider implications of co-creation at a brand level, rather than examining nuances of goods or service brand contexts. This broad brand approach offers a model that is 
relevant across various brand categories and therefore offers a valuable branding tool for practical application.

\section{Customer-Level Antecedents}

Brand engagement, brand self-congruity and category involvement have previously been conceptualized as having a direct influence on CBCB (France et al., 2015). In relation to brand engagement, emerging empirical findings demonstrate the link between engagement and customer co-creation behaviors. Specifically, research shows that engagement significantly influences development (Prahalad and Ramaswamy, 2004), feedback (Kumar et al., 2010), advocacy (Dwivedi, 2015) and helping (Black et al., 2014) behaviors, all of which are proposed, in this paper, as key dimensions of CBCB.

Similarly, empirical support for the direct relationship between brand self-congruity and cocreation behaviors is also evident in the literature (Christodoulides et al., 2012), where research shows that customers who identify with the brand are more willing to participate in voluntary behaviors (Bettencourt, 1997), specifically in development (Christodoulides et al., 2012), feedback (Tronvoll, 2007), advocacy (Ahearne et al., 2005) and helping (Black et al., 2014), all key dimensions of CBCB.

It is in relation to category involvement that the hypothesized model of this paper departs from France et al.'s (2015) propositions. It is argued that the relationship between category involvement and $\mathrm{CBCB}$ is not direct. Rather, research shows that increased customer interest and involvement in the brand category results in enhanced levels of engagement for the preferred brand within the category (Dwivedi, 2015) and strengthens brand self-congruity 
(Kressmann et al., 2006). Ultimately, the increased intrinsic enjoyment derived from interacting with the category (Richins et al., 1992) creates heightened cognitive and affective engagement for the preferred brand, and increased brand self-congruity. On this basis, it is hypothesized that category involvement directly influences brand engagement and brand self-congruity, which in turn are direct drivers of $\mathrm{CBCB}$.

H1a: Category involvement is positively related to customer-brand engagement.

H1b: Category involvement is positively related to brand self-congruity.

H2: Customer-brand engagement has a positive effect on $C B C B$.

H3: Brand self-congruity has a positive effect on $C B C B$.

\section{Brand-Level Antecedents}

Brand-level antecedents are external to customer control but support and encourage customer participation in a range of co-creation behaviors (France et al., 2015). For example, interactive brands are more encouraging of active contributions to the brand (Ind et al., 2012, Labrecque, 2014). Thus, reciprocal relationships are enabled when the customer feels encouraged and supported in their interactions with the brand (France et al., 2016).

Therefore, brand interactivity becomes an enabler for customers to co-create with the brand.

Similarly, brand community membership enables co-creation behaviors through community support and active participation amongst its members (Muñiz and O'Guinn, 2001).

Specifically, brand community membership increases customer participation in development (O'Hern and Rindfleisch, 2010) and increases the customer voice providing brand feedback, word-of-mouth (Healy and McDonagh, 2013) and helping. On this basis, in departure from 
France et al.'s (2015) conceptualization of brand interactivity and brand communities as moderating the relationships between customer-level antecedents and $\mathrm{CBCB}$, a mediating effect is proposed. As such, we hypothesize that:

\author{
H4a: Brand interactivity mediates $C B C B \rightarrow$ customer-brand engagement. \\ H4b: Brand interactivity mediates $C B C B \rightarrow$ brand self-congruity. \\ H5a: Brand community mediates $C B C B \rightarrow$ customer-brand engagement. \\ H5b: Brand community mediates $C B C B \rightarrow$ brand self-congruity.
}

\title{
CBCB Consequence
}

The enhanced value of co-creation behavior upon the organization is conceptually supported (Ramaswamy, 2010). Yet, few studies have considered the implications of co-creation for the co-creating customer, with the exception of France et al. (2015), who propose that perceived brand value is enhanced. When using, buying or even thinking about the brand, the customer is assessing its worth and the ways in which the brand provides value. Customer participation in co-creation is no exception. The fundamental premise of service-dominant logic is that the customer is an active creator of value (Vargo and Lusch, 2004), in an interactive communicative cycle of the customer-brand relationship (Ballantyne et al., 2011). Cocreation of value occurs in brand and consumer interactions but also through network relationships and social interactions (Juntunen, 2012). When a customer consumes, or experiences the brand, the value of the brand is realized (Merz et al., 2009). Therefore, when a customer participates in co-creation behavior, their experience of the brand is altered which impacts perceptions of brand value. For example, CBCB (i.e. development, feedback, advocacy and helping) may lead to additional cognitive brand awareness, emotional 
fulfilment, intrinsic enjoyment, enhanced self-image, and overall improved brand experiences. On this basis, $C B C B$ is hypothesized as having a positive influence on perceived brand value for the customer who co-creates, $(\mathrm{H} 6)$ :

H6: CBCB has a positive effect on customer perceived brand value for the co-creator.

\section{Research Design}

To address the aims of this study, a survey methodology was used. Largely, the survey adopted existing measures which were used verbatim or adapted to context. Scales measuring category involvement (O'Cass, 2004), customer-brand engagement (France et al., 2016), brand self-congruity (De Vries and Carlson, 2014), brand interactivity (Labrecque, 2014), co-creation (Yi and Gong, 2013) and customer-perceived brand value (Cronin et al., 2000) were selected based on proven reliability and validity. Items measuring brand community membership were developed from conceptual discussions of Fournier and Lee (2009), focusing on shared goals and values and formed by 4-items, including measures such as "I share common values with other brand customers" and "I interact with other members of the brand community". All items used a 5-point Likert scale ranging from "strongly disagree" to "strongly agree".

To test the hypothesized model in a broad branding context, a non-probability convenience method is a suitable approach and in line with similar studies in the branding domain (i.e., Celuch et al., 2015, Yi and Gong, 2013). A split-distribution data collection strategy was adopted, using multiple locations and both online and paper-based methods. This strategy 
mitigates concerns for common method bias and provides access to a broad respondent base, without influencing the nature of response (Huang, 2006; Lin and Van Ryzin, 2012). Customers were intercepted while patronizing selected small business enterprises (including Australian fashion and homewares retailers, hairdressers and cafes), where they were asked to complete a survey about that brand. Additionally, respondents were intercepted at an Australia university and asked to nominate a brand and then complete the survey. This research approach enabled the representation of both small and large brands, across diverse goods and service offerings, which was useful in developing a model applicable in broad branding contexts.

\section{Sample Profile}

Data collection resulted in a final dataset of 326 responses, including a well-dispersed mix of respondents across a range of demographic variables, including age (18 to 34 years $=49 \%, 35$ to 54 years $=34 \%$, 55 years and older $=15 \%$, missing=3\%); gender $($ female $=72 \%$, male $=28 \%$, missing=2\%); and income (less than $\$ 50,000=57 \%, \$ 50,000$ to $\$ 100,000=26 \%$, above $\$ 100,000=11 \%$, missing=6\%). In addition, the method of survey completion was well distributed between the paper-based (62\%) and online (38\%) platforms, with statistical analysis confirming no significant differences between the groups. Respondents selected service (62\%) and goods (38\%) brands with statistical analysis confirming no significant difference between the two groups.

\section{Analytical Approach}

Partial Least Squares SEM (PLS-SEM) analysis was used to test the hypotheses of this study. Given the exploratory nature of this study, PLS-SEM was considered the most appropriate 
analytical evaluation tool (Diamantopoulos and Winklhofer, 2001). In particular, PLS is aligned with the goals of this research, which include the explanation of a target construct's variance (Hair et al., 2012) and subsequent prediction (Hair et al., 2013). Alternative SEM covariance based approaches (CB-SEM using Maximum Likelihood Estimation) are more appropriate for theory testing or confirmation; therefore, they do not support the goals of the present study (Hair et al., 2017). Furthermore, PLS-SEM is not sensitive to sample size and avoids indeterminacy problems of other SEM techniques (Jarvis et al., 2003). Over and above the appropriateness of use of PLS to this study, it has also become a widely accepted analytical tool, used for complex modelling situations (Hair et al., 2013). The systematic approach to PLS-SEM analysis was adopted, as recommended by Hair et al. (2016).

\section{Results}

\section{Preliminary Analysis}

SmartPLS 3.0 (Ringle et al., 2015) was used to evaluate the measurement models. Internal consistency assessment, using measures of composite reliability, assured strong internal consistency for all scales (Peterson and Kim, 2013). Next, convergent validity assessments confirmed that scale items accurately measured the desired construct, with average variance extracted (AVE) results greater than .50, demonstrating convergent validity (Hair et al., 2016). Additionally, factor loadings confirmed all final items exceeded .70, representing meaningful performance (Hair et al., 2016), as shown in Table 2. 


\section{Table 2. Psychometric Reflective Measurement Properties}

C.R.

Category Involvement

I find the brand category is very relevant to my life.

The brand category is a significant part of my life.

I am involved with the brand category.

I think about the brand category a lot.

The brand category means a lot to me.

I am interested in the brand category.

I consider the brand category to be a central part of my life.

Customer-Brand Engagement

I am enthusiastic toward the brand.

I am passionate about the brand.

I have a sense of belonging to the brand.

When dealing with the brand, I am deeply engrossed.

When interacting with the brand, I concentrate entirely on the brand.

When involved with the brand, my mind is focused on what is happening. $\quad .76$

Brand Self-Congruity

This brand reflects who I am.

This brand image corresponds to my self-image in many respects.

This brand is exactly how I see myself.

This brand is a lot like me.

Brand Community

I interact with other members of the brand community.

I consider myself to be part of a community of brand users.

I share common goals with other brand customers. $\quad .86$

Brand Interactivity

The brand allows me to communicate directly with it.

The brand listens to what I have to say.

There is good two-way communication with the brand.

The brand encourages me to communicate directly with it. $\quad .90$

The brand would respond to me quickly and efficiently.

Customer Brand Co-Creation Behaviour (СВСВ)

Development

I take photos of myself with the brand and share them with the brand and others. $\quad .71$

I create advertising for the brand and share it with the brand and others.

I develop new products or services for the brand.

I create online content about the brand.

I develop ideas for the brand (e.g., when participating in competitions).

Feedback $\quad .73$

When I have a positive brand experience, I provide them feedback.

I provide useful ideas on how to improve the brand.

If I notice a problem with the brand, I tell an employee, even if it doesn't affect me. $\quad .72$

I tell the brand my ideas for improvement.

Advocacy $\quad .78$

I recommend the brand to others.

I say positive things about the brand to others. $\quad .92$

I spread the good word about the brand.

I encourage my friends and relatives to use the brand. $\quad .90$

Helping $\quad .77$

I help other customers of the brand if they seem to have problems.

I give advice to other customers about the brand. $\quad .88$

I tell others about new things with the brand.

Customer Perceived Brand Value 
To further establish the integrity of the data, discriminant validity, using the Fornell and Larcker (1981) discriminant validity approach, confirmed that correlations did not exceed the square root of the AVE for the constructs. Finally, suitable collinearity was confirmed and no common method bias was observed using Harmon's one factor test (Igbaria et al., 1997), validating the dual mode survey administration method and confirming the integrity of the data.

\section{Hypothesis Testing \& Model Evaluation}

PLS-SEM involves the assessment of the hypothesized model through exploration of path coefficients. Path model analysis and bootstrap analysis (Hair et al., 2016), confirm all hypothesized relationships to be significant at a 95\% confidence level. Specifically, $\mathrm{H} 1 \mathrm{a}$ and H1b were supported, showing that category involvement (CAT) had a positive effect on customer-brand engagement (ENG) and brand self-congruity (CON). H2 was confirmed, providing support for customer-brand engagement (ENG) as a driver of CBCB. H3 was empirically supported, with brand self-congruity (CON) being a second driver of CBCB. H4a, $\mathrm{H} 4 \mathrm{~b}, \mathrm{H} 5 \mathrm{a}$ and $\mathrm{H} 5 \mathrm{~b}$ related to the mediating effects of brand interactivity (INT) and brand community (COM) within the path model. PLS-SEM mediation analysis involved testing firstly the prerequisite directs effects, which were confirmed. Next, multiple mediation analysis confirmed partial mediation in all cases, providing partial support. $\mathrm{H} 6$ proposed that CBCB would have a significant positive effect on customer perceived brand value (VAL). This hypothesis was strongly supported with results indicating a path coefficient of .61 and associated t-value of 17.56. Finally, in terms of overall model evaluation, results of $R^{2}$ analysis of the hypothesized model shows moderate performance of the endogenous 
variables of ENG (.15), CON (.17), INT (.28), COM (.29), CBCB (.51) and VAL (.37), supporting the overall model. Additionally, $f^{2}$ effect and $Q^{2}$ scores indicate statistically sound model performance, validating the overall model, as shown in Figure 1.

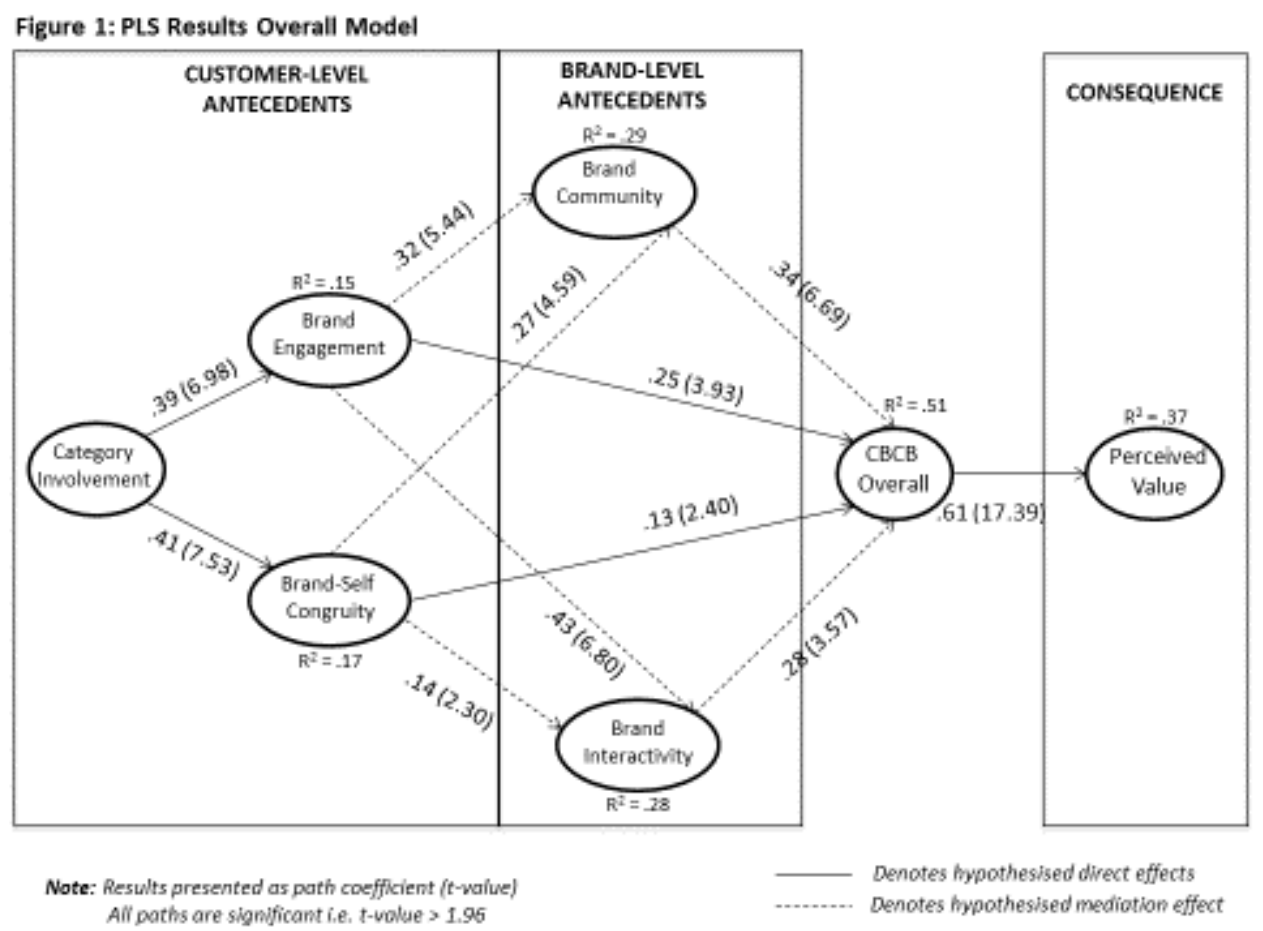

\section{General Discussion}

Few known co-creation studies consider both the definitional nature and dimensionality. In addressing this gap, the research provides new empirical evidence that supports the operationalization of $\mathrm{CBCB}$ as a valid construct with four valid dimensions (i.e. development, feedback, advocacy and helping). A series of tests demonstrate strong reliability and construct validity, and confirm the hypothesized positioning of $\mathrm{CBCB}$ relative to its antecedents and consequences, thus, sanctioning the underlying meaning of $\mathrm{CBCB}$. Moreover, results show that each dimension maintains independence to the other dimensions, while demonstrating a significant relationship between the dimensions to 
support the overall $\mathrm{CBCB}$ construct. All dimensions provide a strong contribution to the overall $\mathrm{CBCB}$ concept and provide confidence in the quality of the items in measuring a consistent and representative concept of CBCB. Notably, the support for CBCB provides a broad brand level co-creation behavior construct for application in a range of brand settings, including both goods and service sectors. Having established $\mathrm{CBCB}$ as an empirically valid concept, the ensuing discussion examines the interplay of relationships surrounding CBCB.

\section{Customer-Level Drivers}

This study acknowledges the strong relationship between engagement and co-creation behavior and highlights that co-creation is a behavioral concept, distinct to engagement (France et al., 2015). In separating these concepts, the model highlights a critical finding; that not all engaged customers will co-create in all instances. However, engagement is a necessary precondition for $\mathrm{CBCB}$. When the customer is passionate and immersed in the brand, they are more likely to participate in co-creation behavior. In this regard, the model has strong alignment with existing research (Hollebeek et al., 2014; Leckie et al., 2016), although, this study introduces the behavioral consequence of engagement in the broader CBCB context.

Findings also support a second brand relational antecedent, brand self-congruity, suggesting that a when a customer's self-image and the image of the brand align, they are more likely to actively participate in voluntary co-creation behavior, supporting previous conceptualizations (Dretsch and Kirmani, 2014; France et al., 2015). While results indicate that congruity has less 
of an influence than engagement upon $\mathrm{CBCB}$, the customer's level of identification with the brand is still important to the activation of $C B C B$.

Finally, in contrast to earlier model conceptualization (France et al., 2015); this study supports the theoretical reasoning that category interest triggers brand relationships, before $\mathrm{CBCB}$ occurs. The indirect influence of category involvement is a new and important acknowledgment, where evoking a customer's interest in the category stimulates a flow-on effect with positive outcomes for both the customer and the brand.

\section{Brand-Level Drivers}

Beyond the customer-level drivers, this study demonstrates that two brand-level antecedents, brand interactivity and brand community, play an enabling role in driving CBCB. The findings support the growing notion that brand communities influence active customer participation (Cova and Pace, 2006). However, this research took a different approach to the measurement of community. Many studies assume brand community membership if, for instance, a customer 'likes' a particular brand on Facebook. Yet, this study takes a relational approach, involving identification as a member of a shared and like-minded brand community. In this relational environment, community is supported as a valid enabler of $\mathrm{CBCB}$, showing that when customers perceive themselves to be a part of a brand community, they are more likely to participate in a range of co-creation behaviors.

Findings support a second brand-level antecedent of co-creation, brand interactivity. The brands technical facilitation of interaction and their demonstration of a genuine desire for connectedness (France et al., 2016) encourages, and enables, the customer to co-create 
(France et al., 2015). Interactivity research largely deals with technical facilitation but the brands authentic desire for interaction has an influence on perception of interactivity (Ilicic and Webster, 2014). These new findings identify that the brand plays an influential role as an enabler of co-creation, encouraging customer participation and providing the means by which to participate.

\section{$\mathrm{CBCB}$ and Brand Value}

The final stage of the model addresses the consequence of $\mathrm{CBCB}$ for those customers who co-create. Co-creation research is built upon the assumption that co-creation leads to enhanced value for the brand (Vargo and Lusch, 2004; Grönroos, 2008). In a consistent manner, the findings provide empirical support for the direct positive influence of $C B C B$ on customer perceived brand value. Previously, value has been explored in relation to the value for the firm (Kumar et al., 2010). However, the findings of this study offer a customer-centric perspective of value co-creation, demonstrating an increase in brand value perceptions for the customer who co-creates and providing a valuable new outlook for value co-creation.

\section{Contributions}

While the findings of this study have served to provide fruitful discussion relating to the nature of $\mathrm{CBCB}$ and the nomological network within which it resides, it is important to explicate the study's contributions for both theory and practice. 


\section{Theoretical Contributions}

This research presents a refined customer-centered view of co-creation in the branding environment. Few known studies consider both the definitional nature of the co-creation concept and its dimensionality. This research addresses both issues, providing a clear and detailed understanding of $\mathrm{CBCB}$. The $\mathrm{CBCB}$ construct is then placed in a network of relationships, which precede and follow $\mathrm{CBCB}$, supporting the underlying meaning of the concept. Importantly, the findings of the study confirm an empirically valid four-dimensional CBCB concept, which addresses all parameters of the construct. This refined criterion for cocreation allowed the previous operationalization of Yi and Gong (2013) to be critically refined, adopting three behaviors (feedback, advocacy and helping), which aligned to the CBCB concept. A fourth CBCB dimension (development) was identified from the literature and demonstrated as a valid dimension of $\mathrm{CBCB}$. Thus, this research contributes a robust new four-dimensional operationalization of the $\mathrm{CBCB}$ construct for future research.

Furthermore, a major contribution lies in validating a strong network of relationships that lead, and arise from, co-creation behavior. Existing theory has a focus on benefits for the firm from CBCB. However, this study takes a customer-centered view of co-creation, demonstrating enhanced brand value perceptions for the co-creator. In doing so, this research offers a valuable theoretical contribution and empirically validates customer cocreation of value.

The model contextualizes co-creation within a customer-brand relationship network, enhancing understanding of the relational influences and outcomes of $\mathrm{CBCB}$, whereby 
customers choose to participate in co-creation based on their relationship with the brand. In particular, engagement and congruity are identified as customer-level relational antecedents with direct impact upon a customer's propensity to co-create. A theoretical contribution lies in the validation of these two variables and, additionally, in the notion that brand relationships are influential in the co-creation context, opening the door for additional customer-level relational variables to be considered. Furthermore, two brand-level relational variables, brand interactivity and brand community, were empirically validated as enabling co-creation. Theoretical merit lies in the verification of these influencers, which are not directly controlled by the customer.

\section{Practical Contributions}

The research maintains a commitment to the development of strong theory with practical application. In this sense, the model becomes a valuable tool for brand managers, informing co-creation strategy. Specifically, the findings suggest that brand managers can encourage participation in $\mathrm{CBCB}$ with the goal of increasing brand value for the customer and ultimately for the firm. The model shows that when customers participate in co-creation behavior, they increase their perceptions of brand value. Brand value is important to brand success in all categories and brand types (Zeithaml, 1988). Yet, arguably, in particular contexts, such as the luxury brand context, as an example, high prices increase the need for realization of brand value (Tynan et al., 2010). In such settings, co-creation may become a strategic tool for enhancing value. 
Development is a seemingly popular co-creation tool utilized by managers in practice, yet it is useful to highlight that feedback, advocacy and helping behavior may be just as effective in increasing brand value for the co-creator. Thus, the customer need not expend excessive effort in co-creation behavior but can enhance perceived brand value with less intensive behavior. Therefore, the $\mathrm{CBCB}$ concept identifies a range of high and low investment cocreation behaviors that the firm may encourage for strategic gain.

Astute brand managers, wishing to increase co-creation may consider a more interactive stance for their brand. Further, when customers perceive themselves to be part of a brand community, they are more inclined to participate in co-creation. Therefore, the firm may be able to proactively build and support the brand community as a method for empowering CBCB.

Additionally, while not directly controllable, brand managers can stimulate customer-level antecedents (i.e. brand engagement, brand self-congruity and category involvement) through their strategic efforts. For example, implementation of strategies to create interest and involvement in the brand may act as a mechanism to drive engagement (Hollebeek et al., 2014). Furthermore, a promotional campaign may highlight some essential variables to enhance perceptions of brand congruity as an indirect method to drive co-creation.

Overall, the research offers valuable contributions to brand management by clearly identifying and empirically verifying the co-creation of brand value through development, feedback, advocacy and helping behavior. Therefore, the use of co-creation strategies as a 
method to enhance customer perceptions of value emerges as a worthwhile opportunity for brand managers.

\section{Limitations and Future Research Directions}

As with all research, it is important to acknowledge the limitations of this study, which are manifested through the data collection method, and generalizability of the results. The use of survey research is often criticized. However, in adopting the use of multi-item scales and employing stringent tests to ensure the integrity of the data, every effort is made to overcome problems. In terms of generalizability, research is commonly constrained by the geographic boundaries in which it is conducted. The cross-sectional approach was selected in this research due to the desire to examine model performance, rather than to describe the prevalence of co-creation within a population. While generalizability may be interpreted as being limited to the Australian population, in fact, Australia represents a typically developed Western culture, with strong similarities to customers in the United States and the United Kingdom. On this basis, the findings may be generalized (albeit, with caution) beyond the geographic boundaries of Australia. Furthermore, in addressing the limitations of this study, the following recommendations for future research are offered.

- First, future research should explore the hypothesized model in alternative brand settings. Specificity of future research in varied brand settings may identify differences in the relative influence of the antecedents to $\mathrm{CBCB}$. Potentially, the influence of engagement may be investigated in service settings where interaction with employees may influence the nature of engagement. In other setting, such as in fashion, brands are highly visible to 
peer networks and often adopted as symbols of self. In this environment, the influence of brand self-congruity may become more influential. Furthermore, in other low involvement categories, such as paper towels, there may not be sufficient interest at the category level to drive co-creation. Where involvement is low due to the low interest, low emotion, low risk and low cost nature, the category may act as a barrier to co-creation, which becomes a challenge for the brand to overcome.

- Second, the findings may be contrasted in various cultural contexts. In particular, findings of this research are relevant in developed Western cultures. However, it may prove insightful to consider the adaptability of the model in less developed economies and/or Eastern cultures. In these environments, cultural and economic influences may impact on the active participation of the customer.

- Third, the influence of multiple stakeholders could provide further insight into the broader co-creation phenomenon. A diverse range of stakeholders are acknowledged as influencing the brand, including employees, suppliers, distributors, and shareholders (Payne et al., 2009). Thus, a potential research opportunity may involve isolating the cocreation experience of each group.

\section{Conclusion}

Overall, the research has adopted a rigorous approach in drawing from the established knowledge in the branding and co-creation domains, and building upon that knowledge, to present a comprehensive model of customer brand co-creation behavior. In achieving 
empirical validation of the model, a number of theoretical and practical contributions are made in relation to the customer perspective of co-creation. In particular, customer-level and brand-level drivers of co-creation are identified, highlighting the consequence of brand value enhancement for the co-creating customer. The customer emphasis provides a new viewpoint for co-creation theory and opens the door for future investigation in this critical research area. 


\section{References}

Ahearne, M., Bhattacharya, C. B. and Gruen, T. 2005. "Antecedents and consequences of customer-company identification: expanding the role of relationship marketing". Journal of Applied Psychology, Vol. 90 No. 3, pp. 574-585.

Ballantyne, D., Frow, P., Varey, R. J. and Payne, A. 2011. "Value propositions as communication practice: Taking a wider view". Industrial Marketing Management, Vol. 40 No.2, pp. 202-210.

Bettencourt, L. A. 1997. "Customer voluntary performance: Customers as partners in service delivery". Journal of Retailing, Vol. 73, pp. 383-406.

Black, H. G., Vincent, L. H. and Skinner, S. J. 2014. "Customers helping customers: Payoffs for linking customers". Journal of Services Marketing, Vol. 28 No.5, pp. 391-401.

Bowden, J. 2009. "Customer engagement: A framework for assessing customer-brand relationships: The case of the restaurant industry". Journal of Hospitality Marketing \& Management, Vol. 18 No. 6, pp. 574-596.

Brodie, R. J., Ilic, A., Juric, B. and Hollebeek, L. 2011. "Consumer engagement in a virtual brand community: An exploratory analysis". Journal of Business Research, Vol. 66 No. 1, pp. 105-114.

Celuch, K., Robinson, N. M., and Walsh, A. M. 2015. "A framework for encouraging retail customer feedback". Journal of Services Marketing, Vol. 29 No. 4, pp. 280-292.

Christodoulides, G., Jevons, C. and Bonhomme, J. 2012. "Memo to marketers: Quantitative evidence for change: How user-generated content really affects brands?". Journal of Advertising Research, Vol. 52 No. 1, pp. 53-64.

Corcoran, M. 2007. "Defining and measuring constructs". The American Journal of Occupational Therapy, Vol. 61, No. 1, pp. 7-8.

Cova, B. and Pace, S. 2006. "Brand community of convenience products: New forms of customer empowerment - the case "my Nutella The Community"". European Journal of Marketing, Vol. 40 No. 9/10, pp. 1087-1105.

Cronin, J. J., Brady, M. K. and Hult, G. T. M. 2000. "Assessing the effects of quality, value, and customer satisfaction on consumer behavioral intentions in service environments". Journal of Retailing, Vol. 76 No. 2, pp. 193-218.

De Vries, L., Gensler, S. \& Leeflang, P. S. 2012. "Popularity of brand posts on brand fan pages: an investigation of the effects of social media marketing". Journal of Interactive Marketing, Vol. 26, pp. 83-91.

De Vries, N. J. and Carlson, J. 2014. "Examining the drivers and brand performance implications of customer engagement with brands in the social media environment". Journal of Brand Management, Vol. 21 No. 6, pp. 495-515.

Diamantopoulos, A. and Winklhofer, H.M. 2001. "Index construction with formative indicators: an alternative to scale development". Journal of Marketing Research, Vol. 38 No. 2, pp. 269-277.

Dretsch, H. J. and Kirmani, A. 2014. "Why are some brand co-creation activities more effective than others?: The effects of brand knowledge potential and self-brand connection on brand engagement intentions". Advances in Consumer Research, Vol. 42, pp. 535-536.

Dwivedi, A. 2015. "A higher-order model of consumer brand engagement and its impact on loyalty intentions". Journal of Retailing and Consumer Services, Vol. 24, pp. 100-109. 
Fetscherin, M., Boulanger, M., Filho, C. G., \& Souki, G. Q. 2014. "The effect of product category on consumer brand relationships". Journal of Product \& Brand Management, Vol. 23 No. 2, pp. 78-89.

Fornell, C. and Larcker, D. F. 1981. "Evaluating structural equation models with unobservable variables and measurement error". Journal of Marketing Research, Vol. 18 No. 1, pp. 39-50.

Fournier, S. and Lee, L. 2009. "Getting brand communities right". Harvard Business Review, Vol. 87, pp. 105-111.

France, C., Merrilees, B. and Miller, D. 2015. "Customer brand co-creation: A conceptual model". Marketing Intelligence \& Planning, Vol. 33 No. 6, pp. 848-864.

France, C., Merrilees, B. and Miller, D. 2016. "An integrated model of customer-brand engagement: Drivers and consequences". Journal of Brand Management, Vol. 23 No. 2, pp. 119-136.

Galvagno, M. and Dalli, D. 2014. "Theory of value co-creation: A systematic literature review". Managing Service Quality, Vol. 24 No. 6, pp. 643-683.

Grönroos, C. 2008. "Service logic revisited: Who creates value? And who co-creates?". European Business Review, Vol. 20 No. 4, pp. 298-314.

Hair, J. F., Hult, G. T. M., Ringle, C. M. and Sarstedt, M. 2016. A Primer On Partial Least Squares Structural Equation Modeling (PLS-SEM), Thousand Oaks, California, Sage Publications.

Hair, J. F., Ringle, C. M. and Sarstedt, M. 2013. "Partial least squares structural equation modeling: rigorous applications, better results and higher acceptance", Long Range Planning, Vol. 46 Nos. 1-2, pp. 1-12.

Hair, J. F., Sarstedt, M., Ringle, C. M. and Mena, J. A. 2012. "An assessment of the use of partial least squares structural equation modeling in marketing research", Journal of the Academy of Marketing Science, Vol. 40 No. 3, pp. 414- 433.

Healy, J. C. and McDonagh, P. 2013. "Consumer roles in brand culture and value co-creation in virtual communities". Journal of Business Research, Vol. 66 No. 9, pp. 1528-1540.

Hollebeek, L. D., Glynn, M. S. and Brodie, R. J. 2014. "Consumer brand engagement in social media: Conceptualization, scale development and validation". Journal of Interactive Marketing, Vol. 28 No. 2, pp. 149-165.

Hoyer, W. D., Chandy, R., Dorotic, M., Krafft, M. and Singh, S. S. 2010. "Consumer cocreation in new product development". Journal of Service Research, Vol. 13 No. 3, pp. 283-296.

Hsieh, S. H. \& Chang, A. 2016. "The Psychological Mechanism of Brand Co-creation Engagement". Journal of Interactive Marketing, Vol. 33 No 13, pp. 13-26.

Huang, H.-M. 2006. "Do print and Web surveys provide the same results?". Computers in Human Behavior, Vol. 22 No. 3, pp. 334-350.

Igbaria, M., Zinatelli, N., Cragg, P. and Angele, L. M. C. 1997. "Personal computing acceptance factors in small firms: A structural equation model". MIS Quarterly, Vol. 21 No. 3, pp. 279-305.

Iglesias, O., Ind, N. \& Alfaro, M. 2013. "The organic view of the brand: A brand value cocreation model". Journal of Brand Management, Vol. 20 No. 8, pp. 670-688.

Ilicic, J. and Webster, C. M. 2014. "Investigating consumer-brand relational authenticity". Journal of Brand Management, Vol. 21 No. 4, pp. 342-363.

Ind, N. and Coates, N. 2013. "The meanings of co-creation". European Business Review, Vol. 25 No. 1, pp. 86-95. 
Ind, N., Fuller, C. and Trevail, C. 2012. Brand Together: How Co-creation Generates Innovation and Re-energizes Brands, Kogan Page, London;Philadelphia.

Ind, N., Iglesias, O. and Schultz, M. 2013. "Building brands together: Emergence and outcomes of co-creation". California Management Review, Vol. 55 No. 3, pp. 5-26.

Jarvis, C.B., MacKenzie, S.B. and Podsakoff, P.M. 2003. "A critical review of construct indicators and measurement model misspecification in marketing and consumer research", Journal of Consumer Research, Vol. 30 No. 2, pp. 199-218.

Juntunen, M. 2012. "Co-creating corporate brands in start-ups". Marketing Intelligence \& Planning, Vol. 30 No. 2, pp. 230-249.

Kim, Y. \& Slotegraaf, R. J. 2015. "Brand-embedded interaction: a dynamic and personalized interaction for co-creation". Marketing Letters, Vol. 27 No. 1, pp. 1-11.

Kressmann, F., Sirgy, M. J., Herrmann, A., Huber, F., Huber, S. and Lee, D. J. 2006. "Direct and indirect effects of self-image congruence on brand loyalty". Journal of Business Research, Vol. 59 No. 9, pp. 955-964.

Kumar, V., Aksoy, L., Donkers, B., Venkatesan, R., Wiesel, T. and Tillmanns, S. 2010. "Undervalued or overvalued customers: Capturing total customer engagement value". Journal of Service Research, Vol. 13 No. 3, pp. 297-310.

Labrecque, L. I. 2014. "Fostering consumer-brand relationships in social media environments: The role of parasocial interaction". Journal of Interactive Marketing, Vol. 28 No. 2, pp. 134-148.

Leckie, C., Nyadzayo, M. W. and Johnson, L. W. 2016. "Antecedents of consumer brand engagement and brand loyalty". Journal of Marketing Management, Vol. 32 No. 5-6, pp. 558-578.

Lin, W. and Van Ryzin, G. G. 2012. "Web and mail surveys: An experimental comparison of methods for nonprofit research". Nonprofit and Voluntary Sector Quarterly, Vol. 41, pp. 1014-1028.

Marzocchi, G., Morandin, G. \& Bergami, M. 2013. "Brand communities: loyal to the community or the brand?". European Journal of Marketing,Vol. 47 No.1/2, pp. 93114.

Merz, M. A., He, Y. and Vargo, S. L. 2009. "The evolving brand logic: A service-dominant logic perspective". Journal of the Academy of Marketing Science, Vol. 37 No. 3, pp. 328344.

Minkiewicz, J., Evans, J. and Bridson, K. 2014. "How do consumers co-create their experiences? An exploration in the heritage sector". Journal of Marketing Management, Vol. 30 No. 1-2, pp. 30-59.

Muñiz, A. M. and O'Guinn, T. C. 2001. "Brand community". Journal of Consumer Research, Vol. 27 No. 4, pp. 412-432.

O'Cass, A. 2004. "Fashion clothing consumption: Antecedents and consequences of fashion clothing involvement". European Journal of Marketing, Vol. 38 No. 7, pp. 869-882.

O'Hern, M. S. and Rindfleisch, A. 2010. "Customer co-creation: A typology and research agenda". Review of Marketing Research, Vol. 6, pp. 84-106.

Payne, A., Storbacka, K. and Frow, P. 2008. "Managing the co-creation of value". Journal of the Academy of Marketing Science, Vol. 36 No. 1, pp. 83-96.

Payne, A., Storbacka, K., Frow, P. and Knox, S. 2009. "Co-creating brands: Diagnosing and designing the relationship experience". Journal of Business Research, Vol. 62 No. 3, pp. 379-389. 
Peterson, R. A. and Kim, Y. 2013. "On the relationship between coefficient alpha and composite reliability". The Journal of Applied Psychology, vol. 98, no. 1, pp. 194-198.

Prahalad, C. K. and Ramaswamy, V. 2004. "Co-creating unique value with customers". Strategy \& Leadership, Vol. 32 No. 3, pp. 4-9.

Ramaswamy, V. 2010. "Competing through co-creation: Innovation at two companies". Strategy \& Leadership, Vol. 38 No. 2, pp. 22-29.

Ramaswamy, V. and Gouillart, F. 2010. The Power of Co-creation, New York, Free Press.

Ramaswamy, V. and Ozcan, K. 2014. The co-creation paradigm, Stanford, California, Stanford Business Books, An Imprint of Stanford University Press.

Richins, M. L., Bloch, P. H. and Mcquarrie, E. F. 1992. "How enduring and situational involvement combine to create involvement responses". Journal of Consumer Psychology, Vol. 1 No. 2, pp. 143-153.

Ringle, C.M., Wende, S. and Becker, J.-M. 2015. "SmartPLS 3", available at: http://www.smartpls.com

Thompson, D. V. and Malaviya, P. 2013. "Consumer-generated ads: Does awareness of advertising co-creation help or hurt persuasion?". Journal of Marketing, 77, 33-47.

Tregua, M., Russo-Spena, T., \& Casbarra, C. 2015. "Being social for social: A co-creation perspective". Journal of Service Theory and Practice, Vol. 25 No. 2, pp. 198-219.

Tronvoll, B. 2007. "Customer complaint behaviour from the perspective of the servicedominant logic of marketing". Managing Service Quality, Vol. 77 No. 3, pp. 33-47.

Tuškej, U., Golob, U. \& Podnar, K. 2013. "The role of consumer-brand identification in building brand relationships". Journal of Business Research, Vol. 66 No. 1, pp. 53-59.

Tynan, C., McKechnie, S. and Chhuon, C. 2010. "Co-creating value for luxury brands". Journal of Business Research, Vol. 63, No. 11, pp. 1156-1163.

Vargo, S. L. and Lusch, R. F. 2004. "Evolving to a new dominant logic for marketing". Journal of Marketing, Vol. 68 No. 1, pp. 1-17.

Vernette, E. \& Hamdi-Kidar, L. 2013. "Co-creation with consumers: who has the competence and wants to cooperate". International Journal of Market Research, Vol. 55 No. 4, pp. 539-561.

Yi, Y. and Gong, T. 2013. "Customer value co-creation behavior: Scale development and validation". Journal of Business Research, Vol. 66 No. 9, pp. 1279-1284.

Zeithaml, V. A. 1988. "Consumer Perceptions of Price, Quality, and Value: A Means-End Model and Synthesis of Evidence". Journal of Marketing, Vol. 52, No. 3, pp. 2-22. 